\title{
PELAYANAN PUBLIK DI DESA
}

\author{
Prof. Dr. Hanif Nurcholis, M.Si \\ Universitas Terbuka \\ hanif@ecampus.ut.ac.id
}

\begin{abstract}
ABSTRAK, Pemerintah desa tidak memberikan pelayanan publik dasar: pendidikan, kesehatan, dan kesejahteraan. Pemerintah desa hanya menarik pajak bumi dan bangunan, melayani surat pengantar ke pemerintah atasan, dan membangun infrastruktur desa dengan cara gotong royong warisan heerendiensten zaman kolonial. Berangkat dari masalah tersebut penelitian kualitatif dilakukan di Desa Loireng, Kecamatan Sayung, Kabupaten Demak. Tujuannya adalah untuk menganalis mengapa pemerintah desa tidak memberikan pelayan publik dasar tersebut. Data diperoleh melalui pengamatan, studi dokumen, dan wawancara. Data yang diperoleh dianalisis secara deskriptif kualitatif. Teori new public service dari Denhardt dipakai sebagai pisau analisis. Penelitian ini menemukan bahwa pemerintah desa bukan lembaga pemerintah formal tapi korporasi komunitas bentukan negara yang tidak dibentuk untuk tujuan memberikan pelayanan publik.
\end{abstract}

Kata kunci: pemerintah desa, state corporatisme, pelayanan publik dasar.

ABSTRACT, Village government isn't deliver basic public services: education, health, and social-economy. It is just levy tax land, legitimate of lettters, and building infrastructue with mutual cooperation as heritage colonial policy, heerendiensten. Base on this problem, the qualitative research conduct in Loireng Village, Sayung Under District, Demak Regency/District, Central J awa Province. The objective of this research is to analysis why the village government does not deliver basic public services. Data has collected by observation, document study, and interview. Data analysed with qualitative descriptive. The new public service theory Denhardt and Denhardt used to analysed it. This research found that village government isn't formal government but state corporatism which not formed to deliver citizen public services.

Key word: village government, state corporation, basci public services.

PENDAHULUAN

Pemandangan umum di desa adalah kantor desa yang kosong pada jam-jam kantor/pelayanan; irigasi pertanian peninggalan penjajah yang tidak berfungsi; warga desa yang sangat repot saat mengurus KTP dan KK dan surat-surat lainnya; ketua RT dan ketua 
RW yang bertindak bak pejabat pemerintah desa; pelayanan kesehatan ibu dan anak yang tidak diurus oleh bukan organ resmi pemerintah desa; warga desa yang dimobilisasi untuk melakukan kerja wajib model heerendiensten zaman kolonial untuk mengerjakan infrastruktur desa yang disebut gotong royong desa; petani yang tidak mendapatkan pelayanan negara dalam usaha pertaniannya; petani yang menyedot air sendiri untuk mengairi sawahnya yang kering; kepala desa yang bergaya hidup borjuis di tengah-tengah rakyatnya yang miskin; perangkat desa yang tidak kompeten menyelenggarakan pemerintahan dan pelayanan publik; kepala desa yang minta uang pologoro atau fee $2-5 \%$ kepada rakyat yang menjual atau membeli tanah; kepala desa yang menjadi calo tanah sehingga mendorong rakyatnya untuk menjual tanahnya; dan banyaknya papan nama terpajang di depan Kantor Desa (BPD, PKK, LPM, Karang Taruna, dan Linmas) yang tidak jelas kegiatannya. Warga desa sejak masa kolonial sampai sekarang tidak mendapatkan pelayanan publik dasar dari pemerintah desa: pendidikan, kesehatan, sosial-ekonomi, dan Tramtibkam (ketenteraman, ketertiban, dan keamanan). Di desa memang ditemui Sekolah Dasar (SD). Di beberapa Desa ditemui Puskesmas Pembantu dan
Koperasi Unit Desa (KUD). Akan tetapi lembaga yang memberikan pelayanan publik bidang pendidikan, kesehatan, dan sosial-ekonomi tersebut bukan milik pemerintah desa. SD, Puskesmas Pembantu, dan KUD adalah milik pemerintah kabupaten.

Di Desa terdapat Kantor Desa. Kantor Desa dipimpin oleh Sekretaris Desa yang bertanggung jawab kepada Kepala Desa. Sekretaris desa ada yang PNS dan ada yang bukan PNS. Akan tetapi, sesuai dengan UU No. 6/2014 sekretaris desa tidak lagi dijabat oleh orang yang berstatus PNS. Sekretaris desa membawahi staf sekretariat yang terdiri atas kepala-kepala urusan dan staf teknis. Di luar sekretaris desa dan stafnya juga terdapat pejabat kewilayahan di bawah langsung kepala desa: kepalakepala dusun.

Kantor Desa lebih banyak mengurus laporan harian, bulanan, tiga bulanan, enam bulanan, dan tahunan ke Kantor Kecamatan dan Kabupaten; pengerahan massa untuk kegiatan yang dikoordinir PKK seperti kegiatan yang dilakukan oleh pengurus Pos Pelayanan Terpadu (Posyandu), koperasi simpan pinjam skala rumah tangga, latihan keterampilan masak memasak dan kerajinan kecil; membantu data pemilih saat Pemilihan Presiden dan Pemilihan Kepala Daerah; dan pengerahan massa 
untuk kerja-wajib model heerendiensten zaman Belanda yang diberi nama baru gotong royong atau gugur gunung. Satu kegiatan penting yang dikendalikan dari Kantor Desa adalah penarikan Pajak Bumi dan Bangunan (PBB) kepada wajib pajak dari warga desa.

Kantor Desa hanya memberikan pelayanan surat-surat yang diperlukan warga desa: surat pengantar untuk mengurus KTP dan KK, surat pengantar untuk memperoleh kartu BPJS, surat pengantar mengurus sertifikat tanah, surat pengantar keterangan miskin (biasanya untuk kepentingan pengobatan di rumah sakit dan bantuan pendidikan Bidikmisi), dan surat keterangan jalan bagi yang berpergian jauh ke luar provinsi. Kantor Desa tidak mempunyai bagian-bagian yang mengurus pendidikan, kesehatan, sosial-ekonomi, dan Tramtibkam (ketentraman, ketertiban, dan keamanan) warga desa. Kondisi pelayanan publik di Desa yang memperihatinkan tersebut perlu dikaji lebih mendalam. Mengapa hal tersebut terjadi? Bukankah tugas Negara melalui lembaga pemerintahnya memberikan pelayanan publik demi menciptakan kesejahteraan rakyat? Untuk mendalami lebih lanjut pelayanan publik di desa dilakukan penelitian di Desa Loireng, Kecamatan Sayung, Kabupaten Demak, Provinsi Jawa Tengah.
Tujuannya adalah untuk mendeskripsikan dan menganalisis pelayanan publik di Desa yang masih memperihatinkan tersebut.

Teori yang digunakan untuk menganalisis data yang diperoleh adalah teori new public service (NPS). Denhardt \& Denhardt (2003) menjelaskan bahwa rakyat harus dipandang sebagai warga negara dalam sistem demokrasi. Rakyat bukan customer sebagaiman dikontruk dalam paradigma new public management (NPM) tapi warga negara, citizen. Sebagai warga negara dalam sistem demokrasi maka Pemerinah wajib memberikan pelayanan publik kepadanya secara adil, merata,, tidak diskriminatif, jujur dan akuntabel. Di samping teori NPS juga digunakan pendekatan historis untuk mempertajam analisis. Pertimbangannya adalah lembaga desa yang ada sekarang tidak tiba-tiba ada tapi merupakan proses pembentukan yang panjang sejak pra kolonial, kolonial, awal kemerdekaan, zaman Orde Lama, zaman Orde Baru, dan era Reformasi.

\section{METODE DAN ANALISIS}

Penelitian ini menggunakan pendekatan post posivistik dengan metode kualitatif. Data diambil melalui pengamatan, studi dokumen, dan wawancara. Pengamatan dilakukan di seluruh perkampungan, persawahan, 
kantor dan balai desa, dan semua lembaga pendidikan. Wawancara dilakukan dengan kepala desa, perangkat desa, dan tokoh masyarakat. Kegiatan penelitian dilakukan pada Maret sampai dengan Agustus 2017 di Desa Loireng, Kecamatan Sayung, Kabupaten Demak, Provinsi Jawa Tengah.

Instrumen untuk mendapatkan data adalah peneliti sendiri. Untuk mendapatkan data melalui wawancara, peneliti menyusun pedoman wawancara kemudian melakukan wawancara dengan nara sumber: kepala desa, pernagkat desa, dan tokoh masyarakat. Untuk mendapatkan data melalui studi dokumen peneliti membaca laporan monografi desa, peta desa, laporan tahunan desa, Rencana Pembangunan J angka Menengah (RPJM) Desa, Rencana Kerja (RK) Desa, dan Anggaran Pendapatan dan Belanja Desa (APBDesa). Pencarian data dengan pengamatan peneliti melakukan pengamatan langsung pada kantor desa, seluruh perkampungan, persawahan, dan kegiatan-kegiatan di desa (Posyandu, pelayanan surat-surat di kantor desa, rapat $B P D$, rapat pengurus desa, rapat RT, dan rapat RW). Data yang terkumpul setelah dilakukan koding dan verifikasi kemudian dianalisis secara deskriptif kualitatif.

\section{HASI L DAN PEMBAHASAN}

Desa Loireng terletak di Kecamatan Sayung, Kabupaten Demak, Provinsi Jawa Tengah. Posisinya berada pada $15 \mathrm{Km}$ di sebelah timur kota Semarang. Dengan mengikuti jalan negara Semarang-Demak Km 14, Desa Loireng berada di sebelah kanan jalan. Sebagai tanda masuk ke Desa Loireng adalah gapura dengan tulisan besar SAYUNG TURI. Dari gapura ini masuk menyusuri jalan kurang lebih 1,3 Km.

Pengurus desa terdiri atas kepala desa, sekretaris desa, lima kepala urusan, dan empat kepala dusun. Kepala desa baru dijabat oleh Nur Hariri yang terpilih pada 2017. Sekretaris desa dijabat oleh Ahmadi yang sudah menjabat sejak 1983. Ia diangkat sebagai PNS berdasarkan UU No. 32/2004. Kepala urusan terdiri atas kepala urusan pembangunan dan kesejahteraan rakyat yang dijabat oleh Hambali dengan staf Rahmat; kepala urusan pemerintahan yang dijabat oleh Munif dengan staf Lely Rahmawati; kepala urusan keuangan yang dijabat oleh Sokip dengan staf Sanwar. Kepala urusan adalah unsur staf yang berada di bawah sekretaris desa. Selain kepala urusan juga terdapat staf teknis yaitu Jogogoyo, Ulu-ulu, dan Modin. Jogoboyo adalah staf yang mengurus keamanan desa, dijabat oleh Nurudzolam; Ulu-ulu adalah staf yang menguru pengairan desa, dijabat oleh Budiono dan Anwar 
Sadat. Modin adalah staf yang mengurus nikah-rujuk-cerai, dijabat oleh A. Hakim. Staf teknis di bawah sekretaris desa. Pejabat lainya adalah kepala dusun. Kepala dusun adalah pejabat kewilayahan yaitu pejabat yang memimpin wilayah sebagai bagian wilayah desa. Ia bertanggung jawab kepada kepala desa. Karena Desa Loireng mempunyai empat dusun maka kepala dusunnya ada empat: Kepala Dusun Loireng Kulon yang dijabat oleh Masruroh, Kepala Dusun Loireng Tengah yang dijabat oleh Muhariroh, Kepala Dusun Loireng Wetan yang dijabat oleh Ngaliman, dan Kepala Dusun Onggorawe yang dijabat oleh Abdul Ghoni. Semua kepala urusan dan kepala dusun statusnya bukan Aparatur Sipil Negara (ASN) sebagaimana diatur dalam UU No. 5/2014.

Meskipun bukan ASN tapi mereka menggunakan seragam dan atribut ASN. Mereka juga bukan pekerja/buruh sebagaimana diatur dalam UU No. 13/2003 tentang Ketenagakerjaan. Jadi, status kepegawaiannya tidak jelas: bukan ASN dan bukan pekerja/buruh. Oleh karena itu, jika terjadi perselisihan kepegawaian/ketenagakerjaan mereka tidak bisa menggunakan UU No. 5/2014 atau UU No. 13/2003 untuk melindungi hak-haknya.

Kepala desa dan perangkat desa tidak mendapat gaji dari pemerintah karena bukan ASN. Sebagai gantinya mereka mendapatkan tanah bengkok dengan hak garap. Artinya selama menjabat mereka dapat menggarap sawah bengkoknya. Jika sudah tidak menjabat mereka tidak bisa lagi menggarap sawahnya. Kepala desa mendapatkan sawah bengkok 24 bau (1 baru $=0,6$ hektar). Sekretaris desa mendapatkan sawah bengkok 12 bau. Perangkat desa mendapatkan sawah bengkok 2,5 bau. Sawah bengkok adalah sawah komunal yang sudah ada sejak zaman penjajahan Belanda. Di bawah kebijakan tanam paksa, cultuur stelsel (1830-1870) semua tanah di desa dijadikan tanah komunal (Angelino, 1931). Dengan menjadikan tanah desa sebagai tanah komunal maka pemerintah dapat dengan mudah mengatur tanah desa untuk kepentingan tanam paksa pada zaman cultuur stelsel dan penyewaan tanah kepada pemodal swasta pada masa liberalisme (18711942). Penggajian kepala desa dan perangkat desa model kolonial tersebut mash digunakan menggaji kepala desa dan perangkat desa sampai sekarang.

Selain mendapatkan gaji berupa tanah bengkok kepala desa dan perangkat desa juga mendapat pendapatan tetap dari Pemerintah Kabupaten Demak per bulan dari sumber ADD (Alokasi Dana Desa). Kepala desa 
mendapat $\mathrm{Rp}$ 2.500.000, sekretaris desa tidak mendapatkan karena ia PNS (kalau di desa lain yang non PNS mendapatkan Rp 1.750.000), dan perangkat desa mendapat Rp 1.250.000. Ketua RT dan ketua RW juga mendapat biaya operasional per bulan Rp 150.000,-

Kantor dan Balai Desa terletak di bagain timur desa. Kantor Desa adalah tempat resmi kepala desa, sekretaris desa, dan perangkat desa berkantor dan memberikan pelayanan publik kepada warga desa. Kantor Desa resminya mulai buka pukul 08.00 dan tutup pukul 13.00 mulai Senin sampai dengan Jumat. Sabtu dan Ahad tutup. Akan tetapi, kantor desa buka pukul 09.00 dan tutup pukul 13.00. Adapun Balai Desa adalah tempat pertemuan warga desa membahas masalah pembangunan dan pelayanan publik desa seperti Musyawarah Desa membahas rencana pembangunan jangka menengah dan rencana pembangunan tahunan, rapat BPD membahas Peraturan Desa, dan pertemuan warga desa lainnya. Perangkat desa yang setiap hari berkantor di Kantor Desa adalah sekretaris desa sedangkan kepala desa dan perangkat desa lainnya tidak demikian. Setiap Senin dan Jumat kepala desa dan semua perangkat desa hadir di Kantor Desa. Akan tetapi, Selasa sampai dengan Jumat tidak semua perangkat desa hadir. Pada hari-hari tersebut perangkat desa hadir dengan cara piket: per hari empat orang. Sekretaris desa hadir setiap hari karena berstatus ASN (PNS) sedangkan kepala desa pada Selasa sampai Jumat lebih banyak absen daripada hadir. Warga desa yang berurusan dengan tanda tangan kepala desa harus meningalkan surat/dokumen yang diajukan di Kantor Desa untuk diambil pada keesokan harinya.

Kegiatan utama pemerintah desa adalah menarik pajak bumi dan bangunan (PBB). Kabupaten menyerahkan data pembayar PBB melalui Camat Sayung. Camat Sayung menyerahkan data tersebut kepada Kepala Desa Loireng. Kegiatan lainnya adalah melayani warga desa yang memerlukan surat pengantar. Warga desa yang mengajukan KTP dan KK tidak bisa dilayani final di Kantor Desa tapi dibuatkan surat pengantar oleh sekretaris desa yang ditandatangani oleh kepala desa. Sebelum datang ke Kantor Desa, pemohon harus mendatangi rumah ketua RT untuk minta tanda tangan. Di sini pemohon bisa langsung ketemu dengan ketua RT dan bisa tidak ketemu karena ketua RT tidak mempunyai jadwal pelayanan. Pemohon umumnya datang malam hari atau hari Ahad karena pada siang hari di luar Ahad ketua RT bekerja di sawah atau di pabrik di kota Semarang. Kalau bisa ketemu langsung dengan ketua RT permohonan langsung dilayani. 
Akan tetapi, kalau ketua RT tidak berada di rumah, anggota keluarganya minta surat ditinggal di rumahnya. Jika demikian, maka surat pengantar tersebut baru bisa diambil esok harinya. Setelah selesai berurusan dengan ketua RT, pemohon mendatangi rumah ketua RW. Di sini juga prosedurnya juga sama dengan berurusan dengan ketua RT. Setelah selesai berurusan dengan ketua RW baik pada hari yang sama atau pada esok harinya, pemohon medatangi Kantor Desa. Di Kantor Desa pemohon diterima oleh perangkat desa dan Sekretaris Desa. Sekretaris Desa membuatkan surat pengantar resmi dan memberi nomor surat. Jika pada saat itu kepala desa berada di Kantor Desa maka pada saat itu juga surat bisa ditanda tangani kepala desa. Akan tetapi, yang banyak terjadi adalah kepala desa tidak berada di tempat. Oleh karena itu, surat pengantar resmi tersebut harus ditinggal dan baru esok harinya diterima pemohon. Setelah mendapat tanda tangan kepala desa, pemohon mendatangi Kantor Kecamatan. Di sini pun surat hanya diterima dan dicatat di buku agenda. Pemohon disuruh pulang dan seminggu atau dua minggu diminta datang untuk difoto (untuk KTP elektronik). Setelah difoto, KTP tidak langsung jadi. Pemohon disuruh pulang dan menunggu dua minggu. Petugas meneruskan data pemohon ke Dinas
Kependudukan dan Catatan Sipil Kabupaten Demak. Nara sumber menceritakan bahwa warga yang belum memiliki KTP elektronik memerlukan waktu lama untuk mendapatkannya. Mulai mengajukan permohonan sampai keluar KTP dan KK-nya memerlukan waktu kurang lebih tiga bulan. Adapun untuk mengurus KK memerlukan waktu satu bulan karena cukup tanda tangan Camat.

Pemerintah desa juga memberikan pelayanan jual beli sawah. Warga desa yang menjual atau membeli tanah mendatangi Kantor Desa. Sekretatis desa dan kepala desa menyiapkan semua dokumen yang diperlukan. Di sini terjadi negosiasi antara kepala desa dengan penjual sawah/tanah untuk menentukan besarnya uang jasa pelayanan. Meskipun sudah ada Peraturan Bupati tentang jasa pelayanan penjualan tanah sebesar $1 \%$ dari harga jual tapi tidak dipatuhi kepala desa. Riilnya kepala desa minta antara $2 \%$ sampai dengan 2,5\% dari harga jual. Uang jasa pelayanan ini dilegitimasi dengan istilah adat: uang pologoro. Istilah pologoro berasal dari praktik pemerintahan desa zaman penjajahan Belanda dimana pemerintah kolonial memberi izin kepada kepala desa untuk minta uang jasa pelayanan atas transaksi jual beli tanah. Di samping uang pologoro, pada zaman penjajahan kepala 
desa juga diberi izin minta uang panyeksen: uang jasa sebagai saksi atas terjadinya transaksi hukum antarparpihak di desa (Kartohadikoesoemo, 1984). Uang penyeksen masih diminta kepada warga desa yang mengadakan keramaian dalam acara menikahkan atau mengkhitankan anaknya. Warga yang mengadakan keramaian minta izin kepad kepala polisi melalui kepala desa. Kepala desa minta uang penyeksen.

Pemerintah desa juga merancang program pembangunan infrastruktur desa dengan biaya dari APBDesa dan swadaya masyarakat. APBDesa bersumber dari hasil penjualan tanah kas desa, alokasi dana desa (ADD) dari Kabupaten, dan Dana Desa dari APBN. Swadaya masyarakat berupa kerja wajib desa yang diuangkan dalam bentuk rupiah. Kerja wajib desa tersebut adalah kerja wajib negara warisan kebijakan pemerintah kolonial yang disebut heerendiensten (Angelino, 1931; Furnifall, 1916, 1956; Suroyo, 2000).

Pemerintah desa merupakan obyek pelaku program dan/atau proyek pemerintah atasan: kecamatan, kabupaten, provinsi, dan pusat. Pemerintah Desa Loireng melaksanakan proyek keluarga berencana dari Kabupaten Demak, membantu kelancaran proyek Mbangun Desa dari Provinsi Jawa Tengah, dan membantu pelaksanaan program TNI Manunggal dari Kodam IV Diponegoro Jawa Tengah dan DIY. Semua program dan proyek tersebut direncanakan oleh pemerintah atasan tanpa melibatkan pemerintah desa. pemerintah desa hanya melaksanakan atau membantu pelaksanaannya saja.

Pemerintah Desa Loireng tidak memberikan pelayanan pendidikan dasar kepada warganya. Di desa ini memang terdapat SD Negeri Loireng tapi bukan milik pemerintah desa. SD Negeri Loireng milik Kabupaten Demak di bawah Dinas Pendidikan Kabupaten. Pemerintah Desa hanya memiliki Taman Kanak-Kanak (TK) yang gedungnya menempati salah satu ruang kelas SD. TK ini gaji guru dan biaya operasionalnya ditanggung oleh Pemerintah Desa dan wali murid.

Pemerintah Desa Loireng tidak memberikan pelayanan kesehatan kepada warga desa. Di desa ini terdapat Bidan Desa. Akan tetapi, ia bukan pegawai pemerintah desa. la pegawai Dinas Kesehatan Kabupaten Demak yang ditugaskan di Desa Loireng. Ia di bawah pembinaan Kepala Puskesmas Kecamatan Sayung. Bidan Desa memberikan pelayanan kebidanan kepada warga desa di bawah tanggung jawab Dinas Kesehatan Kabupaten. Warga desa yang sakit dan yang memerlukan perawatan kesehatan datang ke Puskesmas Kecamatan Sayung milik Kabupaten 
Demak karena di sini tidak ada kantor Puskemas Pembantu.

Pemerintah Desa Loireng tidak memberikan pelayanan sosial-ekonomi kepada warga desa. Di desa ini tidak ada Koperasi Unit Desa (KUD) atau Badan Usaha Milik Desa (BUMDes) sebaga lembaga ekonomi desa. Pemerintah desa tidak mengurus infrastruktur irigasi pertanian peninggalan zaman Belanda yang merupakan tulang punggung produksi pertanian. Infrastruktur irigasi pertanian peninggalan zaman Belanda tersebut sudah rusak parah dan dibiarkan terbengkelai tanpa ada pihak yang bertanggung jawab mengurus dan merawatnya: pemerintah kabupaten, provinsi, atau pusat. Kondisi sosialekonomi sektor pertanian Desa Loireng jatuh ke titik nadir karena infrastruktur irigasinya rusak parah ditambah masuknya air asin akibat air pasang laut Jawa. Sejak sepuluh terakhir air laut Jawa meninggi sehingga memasuki seluruh persawahan di kecamatan Sayung bagian utara. Akibatnya, ratusan hektar sawah tidak bisa ditanami padi. Banyak sawah yang bero. Sebagian sawah ditanami ikan nila, udang, dan bandeng. Akan tetapi, karena warga Desa Loireng tidak mempunyai pengalaman memelihara ikan maka hasilnya tidak maksimal. Menghadapi kondisi yang sangat merugikan petani tersebut pemerintah desa tidak berbuat apa-apa.

Pemerintah Desa Loireng juga tidak memberikan pelayanan bidang kesejahteraan masyarakat. Mata pencaharian warga sebagian besar adalah petani dan buruh tani, sebagian kecil pedagang kecil, beberapa orang mempunyai usaha kecil yaitu pembuatan tempe dan kerupuk, sebagian lagi buruh pabrik dan bangunan di kota Semarang, dan beberapa orang sebagai PNS. Pemerinah desa tidak memberikan pelayanan bidang sarana produksi pertanian: modal usaha, obat-obatan, bibit unggul, dan pupuk. la juga tidak mengurus kegiatan apapun kegiatan petani pasca panen seperti jaminan harga dasar, penyimpanan padi saat harga jatuh, dan pemasaran. Petani yang memiliki sawah kebingungan mengatasi masalah sulitnya air pada musim kemarau dan sulitnya membuang air pada musim hujan. Untuk membantu petani mengatasi masalah ini, pemerintah membentuk lembaga komunitas petani: Perkumpulan Petani Pengguna Air (P3A). P3A difungsikan sebagai wadah petani pengguna air untuk mengatur dan mengurus sendiri masalah pengairan untuk sawah anggotanya. Di sini tampak, pemerintah melempar tanggung jawab atas pelayanan pengairan kepada petani. Pemerintah menyerahkan urusan ini 
kepada petani sendiri atas nama pemberdayaan dan partisipasi masyarakat.

Di Desa Loireng terdapat lembaga kemasyarakatan yang dibentuk oleh masyarakat sendiri yaitu Jamaah Manaqib, Fatayat NU, Ranting NU, Ranting Muhammadiyah, dan Majelis Taklim Salimah. Semua lembaga kemasyarakatan bentukan anggota masyarakat tersebut aktif melakukan kegiatan sesuai dengan kebutuhannya. Umumnya bergerak di bidang keagamaan. Di desa ini juga terdapat lembaga pendidikan yang didirikan oleh masyarakat yaitu PAUD dan SMP Islahiyah dan madrasah diniyah (sekolah agama Islam sore hari).

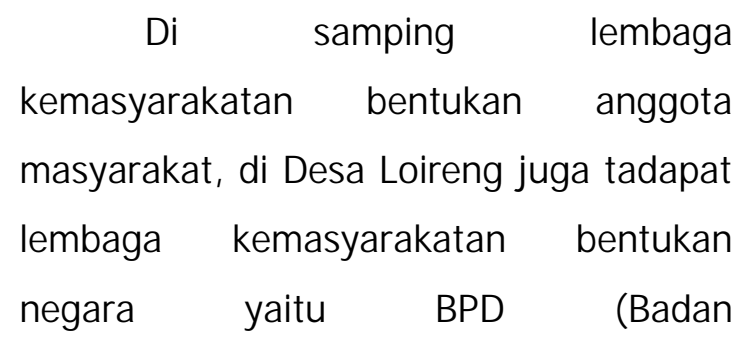
Permusyawartan Desa), LPMD (Lembaga Pemberdayaan Masyarakat Desa), RT (Rukun Tetangga), RW (Rukun Warga), PKK (Pembinaan Kesejahteraan Keluarga), P3A (Perkumpulan Petani Pengguna Air), dan Linmas (Perlindungan Masyarakat). Lembaga kemasyarakatan ini dibentuk oleh negara berdasarkan peraturan perundang-undangan. Lembaga-lembaga tersebut dijadikan alat negara untuk mencapai tujuan negara atas nama partisipasi rakyat. Lembagalembaga kemasyarakatan tersebut sebagian besar hanya papan nama dalam arti tidak ada kegiatannya. Lembaga yang sedikit berfungsi adalah BPD, RT, dan RW. BPD sedikit berfungsi saat dimobilisasi oleh kepala desa untuk mengesahkan RPJM, RK, dan APBDesa. Tanpa dimobilisasi BPD tidak melakukan kegiatan apa-apa. Dalam rapat, BPD hanya mengesahkan Peraturan Desa tentang RPJMDesa, RKDesa, dan APBDesa yang sudah disiapkan oleh kepala desa dan camat berdasarkan arahan dan atasannya. RT dan RW berfungsi saat membahas rencana pembangunan di RT dan RW-nya dan menandatangani surat-surat pengantar yang diajukan warga desa kepada kepala desa.

Dilihat dari perspektif new public service, negara gagal memberikan pelayanan publik di Desa Loireng. Dalam perspektif ini negara wajib memberikan pelayanan publik kepada warga negara. Warga negara bukan customer dalam perspektif new public management tapi citizen dalam negara demokrasi. Warga negara di negara demokrasi wajib diberi pelayanan publik oleh negara tanpa dibedakan tempat tinggalnya, warna kulitnya, partai politiknya, organisasi sosialnya, agamanya, dan preferensi pribadi lainya. Pemerinah wajib 
memberikan pelayanan publik kepada warga negara yang tinggal di desa secara adil, merata, tidak diskriminatif, jujur, dan akuntabel (Denhardt dan Denhardt, 2003). Jika dibandingkan dengan warga negara yang tinggal di wilayah Pemerintah Kota tampak negara melakukan diskriminasi. Warga negara yang tinggal di wilayah Pemerintah Kota tidak diwajbkan melakukan kerja wajib model heerendiensten zaman kolonial.

$$
\text { Kegagalan negara dalam }
$$
memberikan pelayanan publik di Desa Loireng dapat dilihat dari lembaganya. Negara melalui UU No. 6/2014 tidak membentuk organ negara di Desa dengan fungsi memberikan pelayanan publik kepada warga negara yang tinggal di Desa. Negara hanya membentuk korporasi (badan hukum) sipil berbasis komunitas di Desa. Pemerintah desa bukan organ negara formal karena kepala desanya bukan pejabat pemerintah (government official) dan perangkat desanya, kecuali sekretaris desa bukan aparatur sipil negara (ASN). Model ini disbebut state corporatism yaitu pola negara totaliter mencapai tujuan negara dengan membentuk badan hukum sipil (korporasi) atas nama partisipasi rakyat (Schmitter, 1974). Di samping itu, pemerintah desa tidak dibentuk untuk menjalankan fungsi public service. Hal ini terbutkti dengan struktur organisasinya yang tidak dilengkapi dengan departemen atau dinas yang mengurus pelayanan publik dasar. Pemerintah desa tidak mempunyai dinas yang mengurus pelayanan publik dasar: pendidikan, kesehatan, kesejahteraan masyarakat, dan Trantibkam. Pemerintah desa hanya mempunyai staf sekretariat dan pejabat teknis yang tidak terkait dengan pelaksanaan urusan pelayanan publik dasar.

Karena pemerintah desa tidak membentuk organ pelaksana urusan pelayanan dasar, negara lalau membentuk lembaga kemasyarakatan sebagai penggantinya. Negara membentuk RT, RW, BPD, LPMD, PKK, P3A, Karang Taruna, dan Linmas. Semua lembaga kemasyarakatan ini dibentuk negara dengan tujuan membantu pemerintah desa menjalankan fungsinya. Tujuan tersebut sulit terwujud karena karakteristik asli lembaga kemasyarakatan basisnya adalah komunitas yang ditujukan untuk memenuhi kebutuhan anggotanya bukan berbasis otoritas negara untuk membantu tujuan negara (Hunt dan Horton, 1984). Dalam penelitian Philippe Schmitter (1974) model ini dipakai oleh negara-negara totaliter untuk mencapai tujuan negara agar tujuan dapat dicapai lebih efektif.

Karena dibentuk secara sepihak oleh negara maka berfungsi atau tidaknya 
lembaga kemasyarakatan tersebut tergantung pada mobilisasi dan kontrol negara. Di Desa Loireng, RT, RW, BPD, LPMD, PKK, P3A, Karang Taruna, dan Linmas tidak berfungsi sebagaimana keinginan pemerintah. Semua lembaga tersebut baru berfungsi dan berjalan ketika dimobilisasi dan dikontrol oleh kepala desa, camat, dan bupati. Hal ini berbeda dengan lembaga kemasyarakatan bentukan masyarakat sendiri seperti Muslimat NU, Jamaah Manaqib, Ranting NU, Ranting Muhammadiyah, dan Majelis Taklim Salimah. Lembaga kemasyarakatan bentukan masyarkat ini befungsi dengan baik dan tetap ajeg menjalankan kegiatan untuk memenuhi kebutuhan anggotanya. Model pembentukan lembaga kemasyarakatan oleh negara untuk membantu pemerintah desa adalah meniru penjajah Jepang (1942-1945). Pada masa penjajahan Jepang untuk menyukseskan perang Pasifik atau Asia Timur Raya pemerintah membentuk Tonarigumi (RT), Aza (RW), Heiho (Hansip), Keibodan (Kamra), Fujingkai (PKK), dan Seindendan (Karang Taruna) (Aziz, 1954; Kurasawa, 1993). Pada zaman penjajahan Jepang semua lembaga kemasyarakatan yang dibentuk pemerintah tersebut berfungsi dengan baik karena dimobilisasi dan dikontrol dengan sangat ketat dan keras oleh pemerintah (Kurasawa, 1993).

Dilihat dari perspektif historis kegagalan pelayanan publik di Desa Loireng dan desa pada umumnya tidak lepas dari politik desa sejak zaman penjajahan sampai sekarang. Politik desa sejak masa Hindia Belanda sampai sekarang (2017) tetap memposisikan pemerintah desa sebagai instrumen pemerintah pusat dengan tugas pokok menarik pajak bumi dan bangunan, perantara/agen kementerian menjalankan proyek-proyeknya, mengontrol penduduk, dan melaporkan data kependudukan, pertanahan, sosial ekonomi, dan sosial budaya kepada pemerintah atasan. Untuk kepentingan ini pemerintah pusat hanya menjadikan desa sebagai korporasi (badan hukum) bentukan negara berbasis komunitas asli, bukan sebagai organisasi pemerintah resmi.

Kebijakan tersebut asal usulnya adalah kebijakan Raffles di bawah Revenue Instruction 1814 yang menjadikan kepala desa sebagai petugas penarik pajak bumi, landrent (Ball, 1982). Raffles memanfaatkan struktur kekuasaan di desa warisan Kerjajaan Mataram Islam. Dalam struktur kekuasaan Mataram, kepala desa adalah kepala komunitas yang ditundukkan oleh kaki tangan Raja Mataram: adipati, wedono, dan demang. Kemudian Pemerintah Hindia Belanda di 
bawah Regerings Reglemen 1854 Pasal 71 menjadikannya sebagai korporasi (badan hukum) komunitas pribumi (inlandsche gemeenten). Di bawah regulasi tersebut Pemerintah hanya menjadikan lembaga desa sebagai instrumen pusat untuk menarik pajak penduduk dan menguasai tanah desa untuk kepentingan tanam paksa (18301870) dan kepentingan pemodal swasta (1870-1905). Pada masa ini pemerintah tidak memberi pelayanan publik apapun kepada warga desa. Warga desa bahkan dibebani kerja wajib negara (heerendiensten) yang diperhalus dengan istilah gotong royong (Lombard, 2000: 84-89). Warga desa harus melakukan heerendiensten selama 71 hari dalam setahun yang terbagi atas tiga bentuk: 1) heerendiensten untuk desa; 2) heerendiensten untuk pemerintah atasan desa; dan 3) heerendiensten untuk perkebunan swasta (Suroyo, 2000).

Pada masa poilitik etis (19061942), Pemerintah mengatur Desa di bawah IGO 1906 dan IGOB 1938. Di bawah beleid ini status Desa tetap sama dengan sebelumnya tapi Pemerintah memberikan pelayanan publik kepada warga desa dalam bentuk irigasi pertanian, layanan kesehatan, dan administrasi pertanahan (kadaster) melalui pemerintah kabupaten (regenschap) yang dilaksanakan oleh pemerintah district (kawedanan) dan onderdistrict (kecamatan) (Day, 1904; Furnivall, 1916, 1956). Pada zaman pendudukan Jepang (1942-1945), pemerintah sama sekali tidak memberikan pelayanan publik. Pemerintah hanya memobilisasi dan mengontrol penduduk untuk kepentingan perang Asia Timur Raya (Kurasawa, 1993). Pada awal masa kemerdekaan sampai dengan jatuhnya regim Orde Lama (1945-1966), Pemerintah hanya meneruskan kebijakan masa Hindia Belanda: menarik pajak, membangun infra struktur dengan cara kerja-wajib negara atau gotong-royong atau gugur-gunung (heerendiensten), dan mengesahkan surat-surat yang diajukan warga desa. Pada masa Orde Baru, Pemerintah tetap melestarikan model pemerintahan Hindia Belanda ditambah dengan program-program sektoral dari kemenerian pusat. Program-program kementerian pusat yang dilaksanakan di Desa adalah program Bimbingan Massal (BIMAS), Intensfikasi Massal (INMAS), Intensifikasi Umum (INMUM), dan Intensifikasi Khusus (INSUS) dari Departemen Pertanian; program transmigrasi dan padat karya dari Departemen Transmigrasi dan Tenaga Kerja; program keluarga berencana (KB) dari Badan Koordinas Keluarga Berencana Nasional (BKKBN); program kesehatan masyarakat dari Departemen Kesehatan; 
program bebas buta aksara/angka dan wajib belajar dari Departemen Pendidikan dan Kebudayaan; dan program pelatihan keterampilan otomotif, penjahitan, dan kerajinan dari Departemen Sosial. Semua program pelayanan dari pusat tersebut perencanaannya tidak melibatkan pemerintan desa. Pemerintah desa hanya dijadikan agen pelaksana kebijakan Pusat. Pada masa ini di bawah UU No. 5/1974, Pemerintah Pusat memberi kewenangan kepada Kabupaten untuk memberi pelayanan pendidikan dasar dan pra sekolah kepada warga desa. Adapun fungsi dan tugas pemerintah desa tak jauh berbeda dengan pemerintah zaman Hindia Belanda.

$$
\text { Pada masa Reformasi (1999) }
$$

sampai sekarang (2017), Pemerintah Pusat tetap mendominasi pelayanan publik di desa dengan sedikit memberi peran kepada pemerintah kabupaten. Pemerintah pusat menyuruhlaksanakan program padat karya, bantuan beras kepada kelompok miskin desa yang dikenal dengan program Raskin, program bantuan langsung tunai, Alokasi Dana Desa (ADD) dari APBD Kabupaten, dan Dana Desa dari APBN. Sejalan dengan kebijakan desentralisasi dan otonomi daerah, Pemerintah Pusat menyerahkan sebagian urusan kepada kabupaten. Pemerintah Kabupaten memberikan pelayanan pendidikan dasar dan pelayanan kesehatan kepada warga desa. Di samping itu, Pemerintah Kabupaten juga mengalokasikan dana desa dari DAU minimal $10 \%$ dari yang diterima kepada Desa. UU No. 6/2014 tidak menyerahkan urusan pemerintahan apapun kepada Desa. UU ini hanya memberi kewenangan kepada Desa untuk mengatur dan mengurus urusan asal-usul dan urusan skala lokal yang stelsel materiilnya tidak ada.

\section{KESI MPULAN}

Kegagalan pelayanan publik dasar di Desa terletak pada lembaga desa. Lembaga desa bukan organisasi negara resmi dengan fungsi pemberian pelayanan publik kepada warga negara yang tinggal di desa tapi korporasi (badan hukum) komunitas bentukan negara. Korporasi komunitas ini asal-usulnya adalah komunitas desa yang ditundukkan oleh kaki tangan penguasa Kerajaan Mataram Islam. Raffles menjadi komunitas ini sebagai agen penarik pajak. Pemerintah Hindia Belanda kemudian menjadikannya sebagai korporasi komunitas pribumi. Regim Orde Baru menjadikannya sebagai korporasi komunitas gaya perkotaan (struktur organisasinya dirubah menjadi organisasi modern gaya perkotaan). Regim Reformasi sekarang menjadikannya sebagai korporasi komunitas campuran: 
perdesaan dan perkotaan. Pembentukan korporasi komunitas oleh negara disebut state corporatism atau korporatisme negara oleh Philippe Schmiiter (1974).

Di Desa Loireng juga ditemukan data bahwa negara tidak hanya membentuk korporasi komunitas tapi juga membentuk institusi komunitas. Dengan meminjam konsep yang dikemukakan Philippe Schmitter maka pembentukan institusi oleh negara ini bisa disebut state institutionism atau institusionisme negara. Pembentukan BPD, RT, RW, LPMD, P3A, Karang Taruna, dan Linmas adalah wujud institusionisme negara tersebut. State institutionism tidak hanya terjadi di Desa Loireng tapi juga di seluruh desa se Indonesia karena kebijakan ini diatur secara nasional. Dengan demikian, novelty penelitian ini adalah konsep state institutionism desa.

Berdasarkan kesimpulan tersebut disarankan agar lembaga desa direformasi. Lembaga desa diatur kembali sesuai dengan konsepsi founding fathers: Mohammad Yamin dan Soepomo (Sekretariat Negara, 1995; Kusuma, 2009) dan UUD 1945 Pasal 18 (sebelum amandemen). Berdasarkan konsepsi Yamin dan Soepomo serta UUD 1945 Pasal 18, Desa dijadikan daerah otonom kecil berbasis pemerintahan asli dalam sistem pemerintahan daerah (local selfgovernment) modern. Desa tidak dipertahankan terus sebagai korporasi sipil bentukan negara berbasis komunitas pribumi zaman Belanda. Pada era pemerintahan modern yang demokratis pengaturan desa dengan model state corporatism dan state institutionism sudah tidak sesuai dengan kebutuhan masyarakat desa. Masyarakat desa sudah berubah menjadi masyarakat urban yang tinggal di desa. Masyarakat demikian memerlukan pelayanan publik modern oleh lembaga pemerintahan modern, bukan oleh lembaga pemerintahan kuno warisan zaman penjajah Belanda.

\section{UCAPAN TERI MA KASI H}

Kepada Kepala Desa Loireng, Saudara Syamsul Huda, dan Sdr Fauzi saya mengucapkan terima kasih karena telah membantu penelitian ini. Saya juga mengucapkan terima kasih kepada pengelola Perpustakaan Nasional yang telah menyediakan referensi langka dan tua tentang desa.

\section{DAFTAR PUSTAKA}

Angelino, A.D.D. De Kat.. (1931). Colonial Policy Volume II The Dutch East Indies. Netherlands: The Hague Martinus Nijhoff

Aziz, M.A. (1955). Japan's Colonialism and Indonesia, Holland: Martinus Nijhoft, The Hague.

Ball, John. (1982). Indonesia Legal History 1602-1884. Sydney: Oughtereshaw Press 
Day, Clive. (1904). The Policy and

Administration of The

Dutch in Java. London:

Macmillan

Denhardt, Janet Vinzant dan Denhardt,

Robert B. (2003). The New

Public Service: Serving, Not

Steering. New York: M.E.

Sharpe, Inc.

Furnifall, J.S. (1916). Netherlands India A

Study of Plural Economy,

Amsterdam: B.M. Israel BV.

(1956). Colonial Policy and

Practice. A Comparative

Study of Burma and

Netherlands India. USA:

New York University Press.

Horton, Paul B. and Hunt, Chesteer L. (1984). Sociology. Tokyo: McGrawHill

Kartohadikoesoemo, Soetardjo, (1984), Desa, J akarta: Balai Pustaka

Kurasawa, Aiko. (1993). Mobilisasi dan

Kontrol, Studi tentang

Perubahan Sosial di

Pedesaan Jawa 1942-1945.

Jakarta: Grasindo

Kusuma, RM. A.B. (2009). Lahirnya Undang-Undang Dasar 1945. Edisi Revisi. Jakarta: Penerbit Fakulas Hukum Universitas Indonesia.

Schmitter, Philippe C. (1974). "Still the Century of Corporatism?"

The Review of Politics, Vol.

36, No. 1, The New

Corporatism: Social and

Political Structures in the

Iberian World (Jan., 1974),

pp. 85-131. UK: Cambridge

University Press for the

University of Notre Dame

du lac

Sekretariat Negara RI. (1995). Risalah

Sidang-sidang BPUPKI dan

PPKI 28 Mei - 22 Agustus

1945, Jakarta: Setneg.
Suroyo, A.M. Djuliati. (2000). Eksploitasi

Kolonial Abad XIX.

Yogyakarta: Yayasan untuk Indonesia

Regerings Reglement 1854

Undang-Undang Dasar 1945 (Sebelum

Amandemen)

Undang-Undang Dasar 1945 (Sesudah Amandemen)

Inlandsche Gemeente Ordonnantie 1906

Inlandsche Gemeente Ordonnantie Buitengewesten 1938

Undang-Undang Nomor 5 Tahun 1979 tentang Pemerintahan Desa

Undang-Undang Nomor 22 Tahun 1999 tentang Pemerintahan Daerah

Undang-Undang Nomor 13 Tahun 2003 tentang Ketenagakerjaan

Undang-Undang Nomor 5 Tahun 2014 tentang Aparatur Sipil Negara

Undang-Undang Nomor 6 Tahun 2014 tentang Desa 